\title{
Abiotic barriers limit tree invasion but do not hamper native shrub recruitment in invaded stands
}

\author{
Thalita G. Zimmermann • Antonio C. S. Andrade • David M. Richardson
}

Received: 11 April 2016/Accepted: 6 September 2016/Published online: 13 September 2016

(C) Springer International Publishing Switzerland 2016

\begin{abstract}
The interplay between the invasion of alien plant species and re-colonization of native plant species is important for conservation. Sandy coastal plains (called restinga in Brazil) were used as a model system to explore the abiotic barriers that potentially limit the initial establishment of alien and native woody plants in invaded and non-invaded areas. The study tested the influence of light availability, soil type and litter layer on recruitment of a wind-dispersed alien tree (Casuarina equisetifolia) and two birddispersed native shrubs under a Casuarina stand and in the preserved restinga. The effect of soil type and the physical and allelopathic effects of Casuarina litter on seedling emergence of the three species were also evaluated under greenhouse conditions. Low dispersal associated with low seedling emergence and zero survival of young plants (mainly due to microhabitat conditions) apparently prevents the spread of
\end{abstract}

Electronic supplementary material The online version of this article (doi:10.1007/s10530-016-1267-2) contains supplementary material, which is available to authorized users.

T. G. Zimmermann $(\bowtie) \cdot$ A. C. S. Andrade

Laboratório de Sementes, Instituto de Pesquisas Jardim Botânico Do Rio de Janeiro, Rua Pacheco Leão, 915, Jardim Botânico, Rio de Janeiro, RJ 22460-030, Brazil e-mail: thalitagabriella@gmail.com

\section{M. Richardson}

Centre for Invasion Biology, Department of Botany and Zoology, Stellenbosch University, Matieland,

Stellenbosch 7602, South Africa
Casuarina in the preserved restinga. The main cause of low recruitment of native species in the Casuarina stand was the physical barrier of the litter. However, if seeds overcome this physical barrier, the presence of litter improves seedling emergence and survival of young plants, mainly because the litter increases soil moisture. Sowing seeds below litter and planting young plants of native shrubs on litter can improve the re-colonization of native plants in invaded areas. In conclusion, Casuarina invasion on sandy coastal plains is strongly limited by abiotic barriers, but anthropogenic disturbances are altering the key processes that naturally make the restinga resistant to invasion.

Keywords Casuarina equisetifolia $\cdot$ Litter $\cdot$ Seed dispersal $\cdot$ Seedling emergence $\cdot$ Restinga $\cdot$ Tree invasion

\section{Introduction}

Abiotic and biotic barriers often limit the establishment success of alien plants in their new environment (Lonsdale 1999; Levine et al. 2004). On the other hand, invasive plant species modify interspecific interactions and alter ecosystem functions in the new habitat (Hulme 2007; Vilà et al. 2011), creating "novel ecosystems" (i.e. ecosystems that have been irreversibly altered, but which can provide ecological 
values that need to be preserved; Hobbs et al. 2014). Recruitment of native species is often impeded in such ecosystems (Ens and French 2008; de la Penã et al. 2010; Novoa et al. 2012). Although both are important for conservation of the ecosystems, little attention has been given to the concomitant interplay between invasion of alien plant species and native plant recolonization (Emer and Fonseca 2011; FuentesRamírez et al. 2011).

Traits related to reproduction and dispersal are crucial for allowing alien species to overcome a series of barriers to become naturalized or invasive (Blackburn et al. 2011; Richardson and Pyšek 2012). Even if seed dispersal occurs, alien species can only invade if seeds (or other propagules) reach suitable habitat, germinate, and establish (Coutts et al. 2011). Knowledge of the factors that mediate seed germination, seedling survival and growth is therefore essential for determining potential areas of invasion (McAlpine and Jesson 2008; Dechoum et al. 2015). Nonetheless, seed and establishment limitation are usually investigated separately (Warren et al. 2012), which hampers our ability to understand interactions between these potential barriers or opportunities in the invasion process.

When an alien species invades a new habitat, it often modifies abiotic factors, reducing regeneration rates of native species (Ens and French 2008; Hata et al. 2010a; Loydi et al. 2015). Invasive tree species can limit light availability, which may hamper the recruitment and growth of native shade-intolerant species (Fuentes-Ramírez et al. 2011). The moisture content of the soil can be reduced by invasive species, preventing germination of the native vegetation (Novoa et al. 2014). Some alien species can also release allelopathic substances and affect the chemicals of the soil, which may limit the establishment of native species (Bais et al. 2003; Inderjit et al. 2008). Plant litter is another key factor in the recruitment, and may have positive (by decreasing the amplitude of fluctuations in soil temperature and evaporation; Eckstein and Donath 2005; Hovstad and Ohlson 2008) or negative effects (by creating physical and/ or chemical barriers-the former generally stronger the latter; Rotundo and Aguiar 2005; Hovstad and Ohlson 2008) during the early life-cycle stages of the plants (Facelli and Pickett 1991; Xiong and Nilsson 1999). Although invasive species can alter abiotic factors, such as light availability, soil factors, and features of the litter layer, some native species have the capacity to re-colonize invaded areas (Guerrero and Bustamante 2007; Fuentes-Ramírez et al. 2011; Hata et al. 2012). As the removal of an invasive species is usually difficult and expensive (Pimentel et al. 2000; van Wilgen et al. 2016), a better understanding of the factors that limit establishment of native species is required to implement effective recovery efforts in areas affected by invasive species (Ens and French 2008; Fuentes-Ramírez et al. 2011). However, little is known about the potential for recolonization of native plant species in invaded stands (Holmes and Richardson 1999; Emer and Fonseca 2011; Fuentes-Ramírez et al. 2011), especially in stressful environments.

Sandy coastal plains are ecosystems with multiple stressful conditions (e.g. high solar radiation, drought, high temperatures and salinity, burial; Reinert et al. 1997; Hesp and Martínez 2007), which can limit germination and establishment of plants (Scarano 2009). A type of vegetation called restinga (sensu Araújo 1992) occurs in sandy plains along the Brazilian coast, extending from the Equator to below the Tropic of Capricorn-a distance of about $3.900 \mathrm{~km}$ (Lacerda et al. 1993). Some restingas have a patchy structure and are denominated as open scrub vegetation. Extensive areas of sandy coastal plains around the world are covered by open scrub vegetation that may lie behind the coastal thicket or farther inland (Araújo and Pereira 2002). Open scrub vegetation presents two distinct microsites: patches (supporting high species diversity and abundance) and open areas (usually covered by low herbaceous species diversity) (Araújo and Pereira 2002; Correia et al. 2010). Patches have greater water availability and lower irradiance and temperature than open areas (Pugnaire et al. 2004; Gómez-Aparicio et al. 2005). However, shady conditions inside patches can have negative effects on plant recruitment by reducing photosynthesis rates (Callaway and Walker 1997; Hastwell and Facelli 2003). The restinga supports several rare, endemic and threatened species (Araújo and Pereira 2002; Rocha et al. 2007; Scarano 2009). This ecosystem is subject to high levels of degradation (Araújo and Pereira 2002; Rocha et al. 2007), mainly through vegetation removal for housing development and the establishment of alien plant species, such as Casuarina equisetifolia L. (Rocha et al. 2007).

Casuarina equisetifolia is one of the world's most widespread invasive alien tree species (Rejmánek and 
Richardson 2013). It is native to the east coast of Australia and Southeast Asia and it has been planted in coastal regions in many parts of the world (Morton 1980; Parrotta 1993; Potgieter et al. 2014). Casuarina equisetifolia was introduced to Brazil mainly after 1950, when it was widely planted along the coast in the restingas (I3 N Brazil 2016). The species is now naturalized in many parts of the country (Zenni and Ziller 2011; Potgieter et al. 2014). Given the widespread planting and the large extent of climatically suitable areas in the country, there is a large invasion debt (sensu Rouget et al. 2016); further naturalizations and invasions are inevitable in the future. Little recruitment of native species occurs under Casuarina stands, which may be due to the lack of seed dispersal (Hata et al. 2009) and/or inhibition of germination and seedling establishment due to the thick litter accumulation of this tree (Parrotta 1995, 1999; Hata et al. 2009, 2010a, b). However, the main causes of low natural regeneration in areas invaded by this alien species on sandy coastal plains are not known. The invasion of $C$. Equisetifolia in the Brazilian restingas thus provides a good model system to explore the environmental factors that limit the invasion of an alien species and the potential for re-colonization of native plants in invaded areas, considering both seed dispersal to the survival of young plants.

We assessed the influence of three environmental factors expected to be key determinants of early seedling recruitment: light availability, soil type and litter layer. We evaluated: (1) seed dispersal, (2) seedling emergence and seedling establishment, (3) young plants survival and growth of an alien tree $(C$. Equisetifolia) and two native shrubs (Clusia hilariana and Maytenus obtusifolia) in an invasive stand of Casuarina and inside vegetation patches in the restinga, using experimental manipulations of litter. In open areas of the restinga, we only sown seeds and planted young plants of $C$. Equisetifolia, because it is known that regeneration of $C$. hilariana and $M$. obtusifolia is restricted to sites inside patches (Matos 2014). We also undertook a greenhouse experiment to assess how differences in soil type and physical and allelopathic properties of litter affected seedling emergence for the three species. The following hypotheses were examined: (1) $C$. equisetifolia exhibits higher levels of seed dispersal, emergence, survival and growth capacity under its own canopy than in preserved restinga; (2) seed dispersal and recruitment by native shrubs are only successful inside vegetation patches; (3) soil under Casuarina stand has chemical substances that limit the establishment of native species; (4) the litter layer of $C$. equisetifolia decreases rates of recruitment of native plants, and (5) the physical effects of Casuarina litter are stronger than its chemical effects.

\section{Materials and methods}

\section{Study species}

Casuarina equisetifolia L. (Casuarinaceae) (Australian pine or coastal she-oak) is a fast-growing, evergreen tree that attains a height of 10-40 m. The species is wind-pollinated and reproduction is mainly by seeds (Morton 1980; Apfelbaum et al. 1983), but it can also propagate vegetatively (Rentería 2007). Seeds consist mostly of a membranous samara, have dry mass of $0.001 \mathrm{~g}$ (Zimmermann et al. 2016), and are enclosed within a nut borne in a 4-5 $\mathrm{mm}$ long cone (Whistler and Elevitch 2006). Large numbers of seeds are produced (Apfelbaum et al. 1983) and dispersal is mainly by wind (Morton 1980) but also by water (Rentería 2007), although we could find no information on dispersal distances. The species forms a permanent seed bank, with a predicted seed viability of 50 months (Zimmermann et al. 2016).

Clusia hilariana Schltdl. (Clusiaceae), a shadetolerant evergreen native shrub (Matos 2014), occurs along the southeastern and northeastern Brazilian Atlantic Forest (Bittrich et al. 2015). The species can attain $8 \mathrm{~m}$ high, and it is an important component of some woody vegetation patches in the restingas. This shrub is a key nurse plant, providing safe germination sites for other plant species (Scarano 2002; Dias et al. 2006). It is a dioecious species and fruit production occurs between January and May (Faria et al. 2006). Fruits are globular capsules that are rich in lipids (Barroso et al. 1999). Seeds have a dry mass of $0.05 \mathrm{~g}$ (Matos 2014), a thin coat (Braz and de Mattos 2010), an orange aril (Cavalcante et al. 2010) and are dispersed by birds (Gomes 2006). The species has obligate CAM-photosynthesis (Franco et al. 1996) which may favor seedling survival during periods of water shortage (Cavalcante et al. 2010).

Maytenus obtusifolia Mart. (Celastraceae), a shadetolerant (Matos 2014) evergreen native shrub that 
seldom grows taller than $5 \mathrm{~m}$ (Benevides et al. 2013), occurs in several states of northeastern and southeastern Brazil (Lombardi et al. 2015). In the restinga of the Costa do Sol State Park it is one of the most common species in the patchy shrub vegetation (Araújo et al. 2009). Individuals can be dioecious or hermaphrodites (Benevides et al. 2013). Fruit production is mostly between January and April (T.G. Zimmermann, per. obs.). The fruit is a capsule that is red when ripe and opens into two valves; it contains 1-3 seeds surrounded by a white pulp. Seeds have a dry mass of $0.06 \mathrm{~g}$ (Matos 2014) and are dispersed by birds.

\section{Study area}

The study site is located in the restinga of the Costa do Sol State Park $\left(22^{\circ} 58^{\prime} \mathrm{S}, 42^{\circ} 01^{\prime} \mathrm{W}\right.$, sea level $)$, in Arraial do Cabo, state of Rio de Janeiro, Brazil. The PECSol sandy plains occur between the Atlantic Ocean and the Araruama lagoon, the largest hypersaline lagoon in the world. This region is characterized by a hot, semiarid climate, with $800 \mathrm{~mm}$ of annual precipitation, occurring predominantly during summer (November to February) (Barbiére 1984). Annual precipitation in 2014 and 2015 in Arraial do Cabo was 718 and $577 \mathrm{~mm}$, respectively, with minimal rainfall in January $2015(0.2 \mathrm{~mm})$ and maximum rainfall in April 2014 (193 mm) (Figure S1, in the Supporting Information). Periods of low soil water potential are very common in the restinga throughout the year, due to low capacity of the sandy soil to retain water and the occurrence of dry spells during rainy season (Cavalin and de Mattos 2007). Mean annual temperature in the restinga of the PECSol is $25{ }^{\circ} \mathrm{C}$, with minimum and maximum temperatures of $12^{\circ}$ and $36^{\circ} \mathrm{C}$, respectively (Scarano 2002).

Most individuals of $C$. equisetifolia in the restinga of the PECSol were planted close to Araruama Lagoon. Naturalized populations of the species are mainly close to this lagoon, in degraded areas and in abandoned salines. The study area is 25.1 ha in extent and has one of the largest Casuarina stands (2.2 ha) adjoining an uninvaded restinga (22.9 ha) in the park. The $C$. equisetifolia stand has 0.31 individuals $\mathrm{m}^{-2}$ (3.048 ind $\mathrm{ha}^{-1}$ ), height of $7.27 \mathrm{~m} \pm 3.86 \mathrm{~m}$ and diameter at breast height of $5.77 \pm 5.18 \mathrm{~cm}(\mathrm{n}=450)$. Data on photosynthetic photon-flux density (PPFD \%) and red/ far-red light ratio (R:FR; mol mol ${ }^{-1}$ ) in the Casuarina stand were measured at 20 points separated by $20 \mathrm{~m}$.
Values of PPFD \% were $68.5 \pm 11.2 \%$ and R:FR were $1.05 \pm 0.10 \mathrm{~mol} \mathrm{~mol}^{-1}$. Inside patches values of PPFD \% were $1.7 \pm 0.6 \%$ and R:FR were $0.29 \pm 0.05 \mathrm{~mol} \mathrm{~mol}^{-1} \quad$ (Matos 2014). Values of PPFD \% were calculated by taking as reference the mean full sunlight $(100 \%$ PPFD $=$ $2305.3 \mu \mathrm{mol} \mathrm{m} \mathrm{m}^{-2} \mathrm{~s}^{-1}$ ). All measurements were made at midday, on sunny cloud-free days with a radiometer SKR-100 linked to a SpectroSense 2 SKL 904 (Skye Instruments, Llandrindod Wells, UK).

Seed collection and seed viability

Seeds of $C$. equisetifolia and the two native species were collected between February and March 2013 from at least 10 plants per species. Minimum distance between selected seed trees was $10 \mathrm{~m}$. Seeds were removed from the fruit in the laboratory and then stored in sealed plastic bags at $10{ }^{\circ} \mathrm{C}$. Initial seed viability was determined by placing six replicates of 50 seeds on two moist filter papers in Gerbox. Seeds were incubated in a germination chamber at $25{ }^{\circ} \mathrm{C}(C$. hilariana and $M$. obtusifolia) or $30{ }^{\circ} \mathrm{C}$ (C. equisetifolia), at 8/16 h photoperiod. Germination was recorded and distilled water was added every three days. Final germination was $74.2 \pm 7.4 \%$ for $C$. equisetifolia, $80.8 \pm 8.8 \%$ for C. hilariana and $88.4 \pm 7.6 \%$ for M. obtusifolia.

\section{Field experiments}

Experiments were conducted to evaluate (1) seed dispersal, (2) seedling emergence and seedling establishment, (3) young plant survival and growth for the three species in an area invaded by Casuarina and in vegetation patches in the restinga. For $C$. equisetifolia seeds were also sown and young plants were planted in open areas in the restinga (Table 1).

\section{Seed dispersal}

Twenty seed traps were placed in each vegetation type to estimate annual seed dispersal. Beneath Casuarina canopies the traps were set $20 \mathrm{~m}$ apart and inside patches they were separated by $50 \mathrm{~m}$. The difference in the distance between seed traps for each vegetation type was due to the different size of each environment (Casuarina stand $=2.2$ ha; restinga $=22.9$ ha). Seed traps were made from two wooded stakes of $0.5 \mathrm{~m}$ 
Table 1 Description of experimental treatments (field and greenhouse) and experimental design. Study species were an alien species (Casuarina equisetifolia) and two native species (Clusia hilariana and Maytenus obtusifolia)

\begin{tabular}{|c|c|c|c|c|}
\hline Experimental treatments & Conditions & $\begin{array}{l}\text { Experimental } \\
\text { design }\end{array}$ & $\begin{array}{l}\text { Area of each } \\
\text { repetition }\end{array}$ & Assesment \\
\hline \multicolumn{5}{|l|}{ Field } \\
\hline Seed dispersal & & 20 seed traps & $0.5 \mathrm{~m}^{2}$ & Once per month-Annual \\
\hline Seedling & Above, below and without & $6 \times 50$ seeds & $0.04 \mathrm{~m}^{2}$ & \\
\hline Emergence & litter & & & Once per month -4 months \\
\hline Establishment & & & & Once per month -24 months \\
\hline Young plant & With and without litter & $6 \times 5$ young plants & $3 \mathrm{~m}^{2}$ & \\
\hline Survival & & & & Once per month -24 months \\
\hline Growth & & & & Once per year-2 years \\
\hline \multicolumn{5}{|l|}{ Greenhouse } \\
\hline Soil & $\begin{array}{l}\text { Patches, Casuarina stand, } \\
\text { sterilized Casuarina } \text { stand }\end{array}$ & $5 \times 25$ seeds & $0.02 \mathrm{~m}^{2}$ & Once per week -12 weeks \\
\hline Litter & $\begin{array}{l}\text { Below litter, below plastic } \\
\text { fibers, above litter }\end{array}$ & $5 \times 25$ seeds & $0.02 \mathrm{~m}^{2}$ & Once per week-12 weeks \\
\hline
\end{tabular}

Field experiments were conducted in the restinga of the Costa do Sol State Park (Brazil) under three conditions: Casuarina stand, vegetation patches and open areas (only for C. equisetifolia). Greenhouse experiments were conducted in the Botanical Garden of Rio de Janeiro

long, joined by a metal clamp with a diameter of $0.8 \mathrm{~m}$ and surface area of $0.5 \mathrm{~m}^{2}$. A white cloth with $0.1 \mathrm{~mm}$ mesh was fixed inside the seed trap using an elastic band at the metal clamp. The two vegetation types were visited once a month between April 2013 and March 2014. During each visit, cloths were collected and replaced. The collected seeds of the alien species and the two native plants were separated and counted in the laboratory.

\section{Seedling emergence and establishment}

To avoid seed-size effect, the larger and smaller seeds were removed and those with median size were chosen. To separate the seeds of $C$. equisetifolia a seed blower was used. Six plots of $2 \times 2 \mathrm{~m}$ were established in each vegetation type. In Casuarina stand the minimum distance between plots was $20 \mathrm{~m}$. In the restinga, each plot was located inside a patch with $C$. hilariana as a dominant species, with a minimum distance of $50 \mathrm{~m}$ between patches. Minimum size of patches was $6 \times 6 \mathrm{~m}$. Three parallel transects were laid out in each plot and seeds of one species were sown in each transect. For each transect three $0.2 \times 0.2 \mathrm{~m}$ subplots (hereafter the seed subplots) were established, separated by $0.2 \mathrm{~m}$. Each seed sub-plot was surrounded with $1 \mathrm{~mm}^{2}$ pore screen mesh, fixed with four metal wires to prevent seed predation by animals and seed removal by wind. To evaluate effects of litter on seedling emergence, each seed subplot was subjected to a different treatment of seed sowing: (i) above, (ii) below and (iii) without litter layer. Fifty seeds of each species were sown in each seed subplot $(50$ seeds $\times 3$ seed subplot $\times 6$ plots $=900$ seeds/species/vegetation type). The depth of the litter layer was $4 \mathrm{~cm}$. The mean litter depth was measured at 20 random points (Mean $=4.53 \pm$ $2.20 \mathrm{~cm}$ ). As controls, we established two seed subplots $(0.2 \times 0.2 \mathrm{~m})$, with and without litter. These were needed to verify the contribution of the seed bank to seedling emergence. These were not included in analyses as they were only used to assess potential site and treatment contamination. In the open area we sowed only C. equisetifolia seeds without litter. After sowing, each seed subplot was irrigated with $200 \mathrm{ml}$ of water. Sowing seeds were carried out in March 2014, following natural seed dispersal events for the three species. Seedling emergence was defined by shoot emergence. Emergence was recorded monthly as the number of seedlings appearing in the first four months (until July 2014), when emergence had ceased. Seedling emergence proportion $\mathrm{P}(\mathrm{Em})$ was defined as the total number of emerged seedlings divided by the total number of seeds initially disposed in each seed 
subplot (i.e. 50 seeds). Seedling establishment proportion $\mathrm{P}(\mathrm{Es})$ was defined as the total number of seedlings that survived after 24 months of sowing (February 2016) divided by the total number of emerged seedlings (Guerrero and Bustamante 2007).

Recruitment expectancies for each species were calculated based on seed dispersal, emergence and establishment (Vilà and Lloret 2000) in each vegetation type (Casuarina stand and inside vegetation patches) under three different conditions (above, below and without litter). Emergence was estimated by the number of seeds dispersed multiplied by the $\mathrm{P}(\mathrm{Em})$ and establishment was estimated by the emergence multiplied by the $\mathrm{P}(\mathrm{Es})$.

\section{Young plant survival and growth}

Between March and April 2013 seeds were incubated in a germination chamber at $25{ }^{\circ} \mathrm{C}(C$. hilariana and M. obtusifolia) or $30{ }^{\circ} \mathrm{C}$ (C. equisetifolia) at $8 / 16 \mathrm{~h}$ photoperiod. In May 2013 seedlings were transferred to the greenhouse of the Rio de Janeiro Botanical Garden. One month before seedlings were transplanted to the field, the irrigation was reduced for acclimatization. Before the transplant, young plants were measured and the larger and smaller ones were removed to ensure similar sizes within species. The average plant height was $12.58 \pm 2.05 \mathrm{~cm}$ for $C$. equisetifolia, $9.42 \pm 2.06 \mathrm{~cm}$ for $C$. hilariana and $11.57 \pm 1.31 \mathrm{~cm}$ for $M$. obtusifolia, and the average number of leaves was $9.02 \pm 2.14$ for $C$. hilariana and $12.33 \pm 1.48$ for M. obtusifolia. In December 2013, young plants were transplanted to the field. Six plots (4 m x $3 \mathrm{~m}$ ) were established in each vegetation type. The minimum distance between plots in the Casuarina stand was $20 \mathrm{~m}$. In the restinga, plots were inside the same patches as were used for sowing seeds. Inside each plot, six parallel transects, separated by $0.5 \mathrm{~m}$, were established. Thirty young plants were planted in each plot, 10 of each species-five young plants of one species along each transect. To evaluate the effects of litter removal on the survival and growth of young plants, half of the plants were planted with and half without litter layer ( $4 \mathrm{~cm}$ thick). Sixty young plants of each species were planted in each vegetation type. Only young plants of $C$. equisetifolia $(n=30)$ were planted in open areas, without litter. A total of 390 young plants were planted (30 young plants $\times 3$ species $\times 2$ conditions of litter $\times 2$ vegetation types +30 young plants of $C$. equisetifolia in the open area $=390$ ). Young plants were separated by $50 \mathrm{~cm}$ to avoid direct effects of competition. All plants were labeled on the day of planting. After planting, each young plant was irrigated with $100 \mathrm{ml}$ of water. The survival of young plants was monitored monthly over 15 months and the final evaluation was done after 24 months (December 2015). At the beginning of the experiment, the end of the 1 year (December 2014) and the end of the 2 year (December 2015) the height and total number of leaves of each living young plant was noted. The number of leaves was not counted for C. equisetifolia as the leaves are too small to be easily counted.

\section{Greenhouse experiments}

To evaluate the effects of soil type and physical and allelopathic properties of litter on emergence of seedlings of the three species, experiments were conducted in the greenhouse of the Rio de Janeiro Botanical Garden, between March and June 2013 (Table 1).

Soil samples and litter were collected in March 2013. Soil samples were collected in the Casuarina stand and inside vegetation patches in the restinga. In the Casuarina stand six random sites $(0.5 \times 0.5 \mathrm{~m})$ were selected near a $C$. equisetifolia individual to collect sandy soil. In the restinga, soil samples were taken from sites $(0.5 \times 0.5 \mathrm{~m})$ inside the patches where seeds had been sown and young plants planted. Litter was removed prior to soil collection. Soil samples were taken from the top $10 \mathrm{~cm}$ at each point. Half the amount of soil collected in the Casuarina stand was sterilized by autoclaving $\left(1.0 \mathrm{KgF} \mathrm{cm}^{-2}\right.$ and $120^{\circ} \mathrm{C}$ ) to remove any secondary metabolites. In the greenhouse, seeds were sown under three conditions: (1) Casuarina stand soil, (2) sterilized Casuarina stand soil, and (3) soil from patches. Seeds were buried at a depth of $2 \mathrm{~cm}$ in the soil.

Casuarina equisetifolia litter was also collected at six random points. Litter was mixed and air dried before the experiment. To test the physical effect of litter, seeds were buried in vermiculite and covered with litter (below-litter treatment) or placed above the litter layer (above-litter treatment). To determine the chemical effect of litter, seeds were buried in vermiculite and covered by plastic fibers (below plastic fiber treatment). Plastic fibers were of similar size and shape 
to C. equisetifolia litter. As plastic does not produce allelopathic compounds (cf. Facelli and Picket 1991), release of allelopathic substances from litter would decrease emergence under litter in relation to plastic fibers, being attributable to a chemical effect. However, if negative effects on seedling emergence occur in both litter and plastic fibers, these would be attributable to a physical effect. The thickness of litter layer and plastic fibers applied was $4 \mathrm{~cm}$

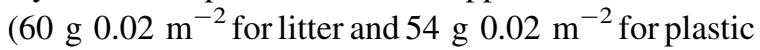
fibers). As control, seeds were buried in vermiculite.

Treatments consisted of 25 seeds of each species sown in 2 - $\mathrm{L}$ pots $\left(0.02 \mathrm{~m}^{2}\right.$, with $16 \mathrm{~cm}$ in length $\mathrm{x}$ $12 \mathrm{~cm}$ in width $\mathrm{x} 10.5 \mathrm{~cm}$ in height), arranged in five blocks (replicates). Treatments were assigned randomly to pots within each block (randomized block design). Each pot was filled with $4 \mathrm{~cm}(750 \mathrm{ml})$ of soil or vermiculite. Experimental pots were watered once or twice a week. Substrate moisture was monitored weekly from three soil samples per treatment, as gravimetric moisture content $\left(103{ }^{\circ} \mathrm{C}\right.$ for $\left.24 \mathrm{~h}\right)$. Seedling emergence (shoot emergence) was recorded every week for 3 months, when emergence had ceased.

\section{Data analysis}

To test differences between seed dispersal of the three species in relation to vegetation type (Casuarina stand and vegetation patches) we used the Mann-Whitney U test, as the Shapiro-Wilk test revealed that the data did not conform to expectations of normality.

Generalized linear mixed models (GLMM) for nested data were used to evaluate the seedling emergence and establishment in the field. The response variable was the proportion of seedling emergence after four months and seedling establishment after 24 months. The Binomial distribution was assumed for the response variable and the logit function for the relationship between the response and explanatory variables. The explanatory variables vegetation type (Casuarina stand and patches), seed sowing position (above, below and without litter), and the interaction between these factors were initially considered fixed effects. As the variables were highly correlated, the inclusion or exclusion of fixed effects for each species was based on Akaike Information Criterion values calculated using maximum likelihood. Seed subplots were spatially dependent, whereas plots were considered replicates of each vegetation type and inserted into the model as a random effect. The GLMMs were performed with random intercepts and slopes. The mixed model was fitted using maximum likelihood and adaptive Gauss-Hermite quadrature to the deviance.

To assess the survival of young plants, the KaplanMeier product limit method was used to estimate the survival function, and a Log-rank test was used to test for significant differences in survival curves among treatments. Cox regression was used to evaluate the effects of vegetation type, presence of litter and their interactions on probability of the death of young plants.

The annual growth of young plants was assessed by examining the difference in height and number of leaves at the end of the first year compared to the beginning of the experiment ( $\Delta$ height or number of leaves year one $=$ time 12 months-time 0 month), and at the end of the second year compared to the end of the first year ( $\Delta$ height or number of leaves year two $=$ time 24 months - time 12 months) for each surveyed young plant. Generalized linear models (GLM) were used to evaluate differences in the growth in the first (2014) and in the 2 year (2015) between the treatments. The response variable was the height increment and the increase of the number of leaves per year. The explanatory variables vegetation type (Casuarina stand and patches) and presence of litter (with and without litter) were used as fixed effects. The Gaussian distribution was assumed for the response variable and the identity function for the relationship between the response and explanatory variables.

In the greenhouse, the differences in soil type and effect of litter in the emergence percentage and emergence rate were tested using a factorial ANOVA, followed by a post hoc Tukey's test $(p<0.05)$. Before performing ANOVA, data were analyzed for normality using the Kolmogorov-Smirnov test and for homogeneity of variance using the Levene's test. For data that did not show normality and/or variance homogeneity, emergence percentage was arcsine $\sqrt{ }$ transformed and germination rate transformed to $\log (\mathrm{x}+1)($ Zar 1999).

All statistical analyses were done with $\mathrm{R}$ version 3.0.3 (R Development Core Team 2014), using the 'Ime4' package for GLMM and GLM, 'survival' package for survival analysis and'stats' for MannWhitney U test. Figures were performed with R and Origin (version 8.0, OriginLab, MA, Cary, NC, USA). 


\section{Results}

\section{Seed dispersal}

Seed dispersal of C. equisetifolia occurred year-round, with the highest number of dispersed seeds recorded in February and March. For $C$. hilariana, the highest seed dispersal occurred in December and March, and for $M$. obtusifolia most seed dispersal took place between January and February (Fig. 1). The average number of C. equisetifolia seeds dispersed over a year was higher in the Casuarina stand than inside patches $(U<0.001 ; p<0.001)$. In relation to the native species, the average number of $C$. hilariana dispersed seeds was higher inside patches $(U=35, p=0.03)$, but for $M$. obtusifolia there was no significant difference in the average number of seeds dispersed between Casuarina stand and inside vegetation patches $(U=65, p=0.71)$ (Table 2$)$.

Seedling emergence and establishment

There was no significant difference in seedling emergence between the two vegetation types for the three species (Table 3). There was virtually no seedling emergence $(\mathrm{P}(\mathrm{Em}))$ of $C$. equisetifolia; only one seedling emerged in each vegetation type, and these all died after one month (Table 4). For the two native species, the position of seed sowing had a significant effect on emergence, with most seedling emergence occurring for seeds sown below litter, and there was no difference between above- and withoutlitter treatments (Table 3). For C. hilariana, seedling emergence occurred in the Casuarina stand only for seeds sown below litter, and inside patches for seeds sown below- and above-litter, but all seedlings died within 24 months. Maytenus obtusifolia was the species with the highest emergence (Table 4). The interaction between vegetation and seed sowing position was only significant for emergence of $M$. obtusifolia, for which the highest value was in the Casuarina stand below litter (Table 3 and 4). No seedlings emerged from the control seed subplots.

The probability of a seed becoming an established seedling was zero for $C$. equisetifolia and C. hilariana in both vegetation types within 2 years. Maytenus obtusifolia was the only species for which seedlings survived to 24 months; the values of establishment proportion $(\mathrm{P}(\mathrm{Es}))$ ranged between $0.02( \pm 0.04)$ and $1.00( \pm 0.00)$ (Table 4). There was no effect of the vegetation type and litter on the establishment of $M$. obtusifolia seedlings (Table 3 ).

Emerged seedling represented $0.3 \%$ of recorded seed dispersal for $C$. equisetifolia in both the
Fig. 1 Total number of seeds dispersed over one year (April 2013 to March 2014) of Casuarina equisetifolia (opened circle), Clusia hilariana (inverted filled triangle) and Maytenus obtusifolia (opened triangle) under the Casuarina stand (upper) and vegetation patches (lower), in the restinga of the Costa do Sol State Park (Brazil). Note the y-axis break in both graphs

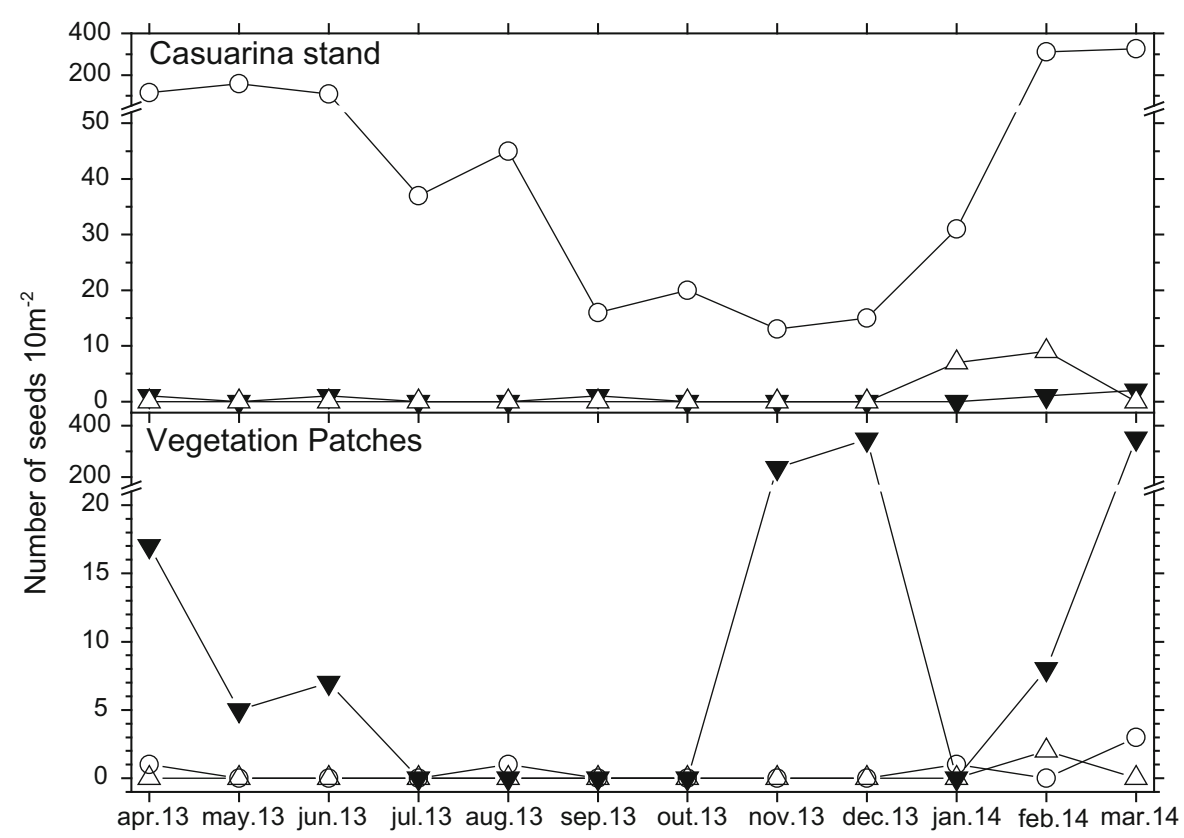


Table 2 Mean ( \pm S.D.) number of seeds dispersed of Casuarina equisetifolia, Clusia hilariana and Maytenus obtusifolia over one year (May 2013 to April 2014), under the Casuarina stand and vegetation patches in the restinga of the Costa do Sol State Park (Brazil)

\begin{tabular}{|c|c|c|c|c|}
\hline \multirow[t]{2}{*}{ Species } & \multicolumn{4}{|l|}{ Seeds $\mathrm{m}^{-2}$ year $^{-1}$} \\
\hline & Casuarina stand & Patches & $U$ & $p$ \\
\hline C. equisetifolia & $199.50 \pm 225.06 \mathrm{a}$ & $1.0 \pm 1.81 \mathrm{~b}$ & $<0.001$ & $<0.001$ \\
\hline C. hilariana & $1.0 \pm 1.35 \mathrm{~b}$ & $161.67 \pm 283.10 \mathrm{a}$ & 35 & 0.03 \\
\hline M. obtusifolia & $2.67 \pm 6.28 \mathrm{a}$ & $0.33 \pm 1.15 \mathrm{a}$ & 65 & 0.71 \\
\hline
\end{tabular}

In bold are significant values (Mann-Whitney $\mathrm{U}$ test; $p<0.05$ )

Different letters indicate significant differences between number of seeds dispersed. Mann-Whitney $\mathrm{U}$ test $(p<0.05)$

Table 3 Statistics for fixed effects of generalized linear mixed model for seedling emergence (after 4 months of seed sowing) and establishment (after 24 months of seed sowing) in relation to vegetation types (Casuarina stand and vegetation patches) and seed sowing position (above-litter, below-litter and without-litter) in the restinga of the Costa do Sol State Park (Brazil)
In bold are significant values $(p<0.05)$

\begin{tabular}{|c|c|c|c|c|}
\hline Variable & Estimate & SE & $Z$ value & $P$ \\
\hline \multicolumn{5}{|l|}{ Casuarina equisetifolia (emergence) } \\
\hline Intercept & -6.39 & 1.23 & -5.216 & $<0.001$ \\
\hline Vegetation patches & $1.67 \mathrm{e}^{-12}$ & 1.42 & 0.000 & 1.000 \\
\hline Below-litter & $-2.00 \mathrm{e}^{+1}$ & $1.34 \mathrm{e}^{+4}$ & -0.001 & 0.999 \\
\hline Without-litter & $4.84 \mathrm{e}^{-15}$ & 1.42 & 0.000 & 1.000 \\
\hline \multicolumn{5}{|l|}{ Clusia hilariana (emergence) } \\
\hline Intercept & -4.24 & 0.56 & -7.514 & $<0.001$ \\
\hline Vegetation patches & -2.78 & 1.64 & -1.700 & 0.089 \\
\hline Below-litter & 1.44 & 0.39 & 3.722 & $<0.001$ \\
\hline Without-litter & -20.87 & 6722.16 & -0.003 & 0.997 \\
\hline \multicolumn{5}{|l|}{ Maytenus obtusifolia (emergence) } \\
\hline Intercept & -5.57 & 0.90 & -6.192 & $<0.001$ \\
\hline Vegetation patches & 2.27 & 1.37 & 1.658 & 0.097 \\
\hline Below-litter & 4.91 & 0.73 & 6.736 & $<0.001$ \\
\hline Without-litter & 0.41 & 0.92 & 0.447 & 0.655 \\
\hline Vegetation patches $\times$ below-litter & -4.37 & 0.77 & -5.639 & $<0.001$ \\
\hline Vegetation patches $\times$ without-litter & 0.19 & 0.96 & 0.196 & 0.844 \\
\hline \multicolumn{5}{|l|}{ Maytenus obtusifolia (establishment) } \\
\hline Intercept & 0.21 & 0.62 & 0.335 & 0.737 \\
\hline Vegetation patches & -1.05 & 0.63 & -1.655 & 0.098 \\
\hline Below-litter & -0.39 & 0.53 & -0.751 & 0.453 \\
\hline Without-litter & 0.92 & 0.54 & 1.72 & 0.085 \\
\hline
\end{tabular}

Casuarina stand above litter and inside vegetation patches without litter (Fig. 2). Irrespective of the number of seeds present in the seedfall, seedling emergence was low and at the end of the recruitment process no seedlings of $C$. hilariana survived in either vegetation type (Fig. 2). For M. obtusifolia, seedling establishment represented $14.4 \%$ of dispersed seeds in the Casuarina stand below litter, inside vegetation patches establishment was $4.2 \%$ of dispersed seeds (Fig. 2).
Young plant survival and growth

The highest survival probability of young plants of $C$. equisetifolia was in the Casuarina stand. All plants died inside patches and open area in less than 13 months (Fig. 3a). The risk of C. equisetifolia death inside patches was 32 times and in open area 30 times higher than in the Casuarina stand (Hazard Ratio (HR) 32.31, Wald's $p$ value $<0.001$; HR 30.37, Wald's $p$ value $<0.001$, respectively). There was no 
Table 4 Mean ( \pm S.D) emergence (Em-after 4 months of sowing) and establishment (Es-after 24 months of sowing) proportion of Casuarina equisetifolia, Clusia hilariana and Maytenus obtusifolia seedlings under Casuarina stand and inside vegetation patches, in the restinga of the Costa do Sol State Park (Brazil)

\begin{tabular}{llll}
\hline & C. equisetifolia & C. hilariana & M. obtusifolia \\
\hline P(Em): Seedling emergence proportion & & & \\
Casuarina stand above litter & $0.003 \pm 0.008$ & 0 & $0.007 \pm 0.010$ \\
Casuarina stand below litter & 0 & $0.10 \pm 0.09$ & $0.39 \pm 0.26$ \\
Casuarina stand without litter & 0 & 0 & $0.01 \pm 0.01$ \\
Patchy above litter & 0 & $0.03 \pm 0.07$ & $0.11 \pm 0.17$ \\
Patchy below litter & 0 & $0.02 \pm 0.03$ & $0.16 \pm 0.19$ \\
Patchy without litter & $0.003 \pm 0.008$ & 0 & $0.17 \pm 0.24$ \\
P(Es): Seedling establishment proportion & & \\
Casuarina stand above litter & 0 & 0 & $1.00 \pm 0.00$ \\
Casuarina stand below litter & 0 & 0 & $0.37 \pm 0.16$ \\
Casuarina stand without litter & 0 & 0 & $0.67 \pm 0.01$ \\
Patchy above litter & 0 & 0 & $0.31 \pm 0.13$ \\
Patchy below litter & 0 & 0 & $0.20 \pm 0.04$ \\
Patchy without litter & 0 & 0 & $0.35 \pm 0.18$ \\
\hline
\end{tabular}
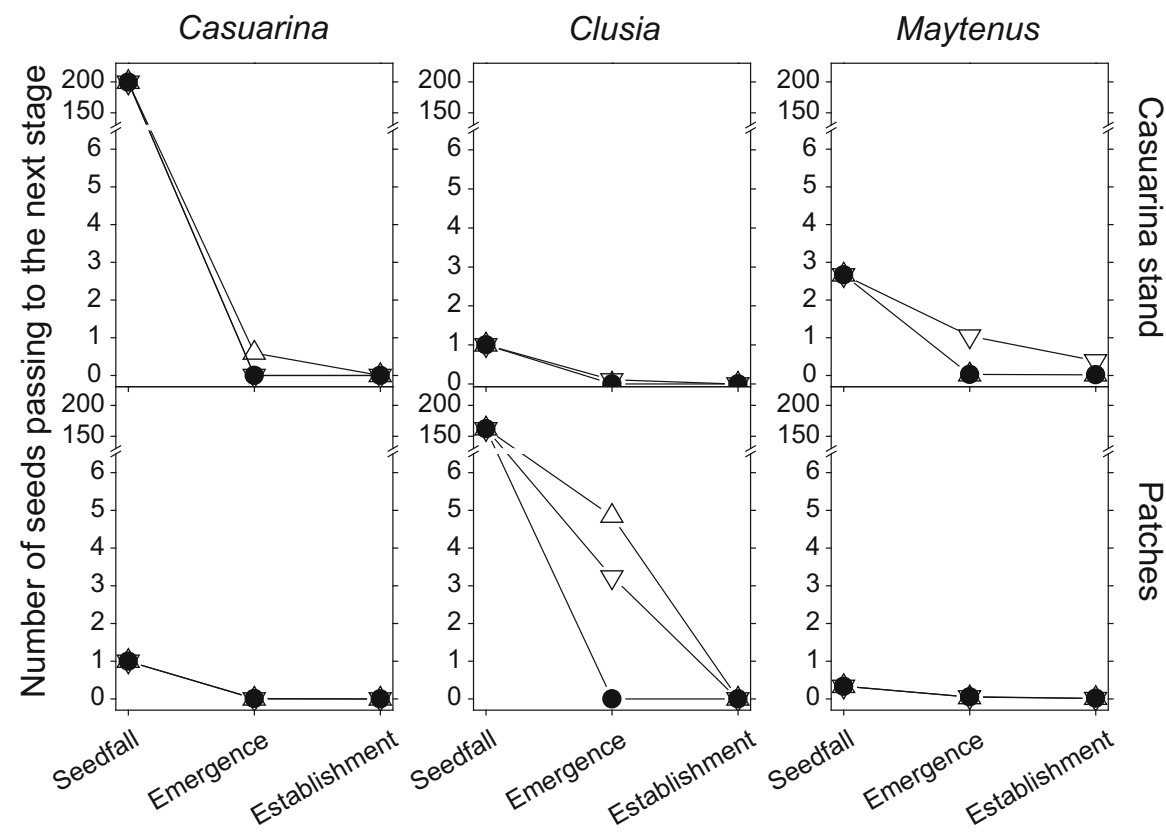

Fig. 2 Recruitment expectancies $\left(\mathrm{m}^{-2}\right)$ for seedlings of $\mathrm{Ca}$ suarina equisetifolia, Clusia hilariana and Maytenus obtusifolia under the Casuarina stand (upper) and vegetation patches (lower), in the restinga of the Costa do Sol State Park (Brazil). Seed sowing above litter (triangle), below litter (inverted triangle) and without litter (closed circle). Reproductive stage:

significant influence of litter in the survival of $C$. equisetifolia (HR 1.44, Wald's $p$ value $=0.23$ ).

The probability of survival of young plants of $C$. hilariana was significantly lower in the Casuarina stand without litter than under other conditions
Mean seedfall over 1 year (April 2013 to March 2014); Mean cumulative seedling emergence after 4 months of sowing (July 2014); Mean Seedling establishment after 24 months of sowing (February 2016). Proportion of seedling emergence and establishment (Table 3) adjusting for the number of seeds dispersed (Table 2). Note the y-axis break in the graphs

(Fig. 3b). There was no significant difference between survival rates of $C$. hilariana in relation to the vegetation type (HR 0.28 Wald's $p$ value $=0.60$ ). Litter layer had no significant influence on C. hilariana survival inside patches (HR 1.78, Wald's 
Fig. 3 Survival probability for young plants of Casuarina equisetifolia (a), Clusia hilariana (b) and Maytenus obtusifolia (c) transplanted to Casuarina stand with litter and without litter, vegetation patches with litter and without litter and open area $(C$. equisetifolia) in the restinga of the Costa do Sol State Park (Brazil). Monthly evaluations during 24 months (January 2014 until December 2015). Survival analysis was performed with the Kaplan-Meier product limit method. The letter codes indicate homogeneous groups (Log-rank test, $p<0.05$ )

$p$ value $=0.18)$, but the probability of death was almost seven times higher without litter than with litter in the Casuarina stand (HR 6.86, Wald's $p$ value $=0.009$ )

Likewise, the lowest survival rate of young plants of $M$. obtusifolia occurred in the Casuarina stand without litter (Fig. 3c). The risk of M. obtusifolia death was ten times higher in the Casuarina stand than in patches (HR 10.1, Wald's $p$ value $=0.001)$. There was no significant difference on survival rates in relation to the presence of litter inside patches (HR 1.31 , Wald's $p$ value $=0.25$ ). However, in the Casuarina stand the probability of death of $M$. obtusifolia without litter was five times higher than with the presence of litter layer (HR 5.32, Wald's $p$ value $=0.02$ ) .

After 24 months in the Casuarina stand, the highest survival probability was for C. equisetifolia (42\%). There was no significant difference between survival rates of the two native species ( $18.0 \%$ for C. hilariana and $25 \%$ for M. obtusifolia; Figure S2a). The risk of death in the Casuarina stand was almost 13 times higher without litter than with litter (HR 12.71, Wald's $p$ value $<0.001$ ) after 24 months (Figure $\mathrm{S} 2 \mathrm{~b}$ ). On the other hand, after 24 months inside vegetation patches, M. obtusifolia was the species with the highest probability of survival $(43.3 \%)$, followed by $C$. hilariana $(6.0 \%)$; there was zero survival for $C$. equisetifolia (Figure S2c). There was no significant difference between survival rates with and without a litter layer (HR 1.43, Wald's $p$ value $=0.23$ ) after 24 months inside patches (Figure S2d). In total, after two years, $34.2 \%$ of young plants of M. obtusifolia remained alive. For $C$. hilariana and $C$. equisetifolia, only 12.0 and $19.1 \%$ of young plants survived, respectively. The overall survival rate after 24 months in the Casuarina stand was 25.2 and $17.5 \%$ inside patches.
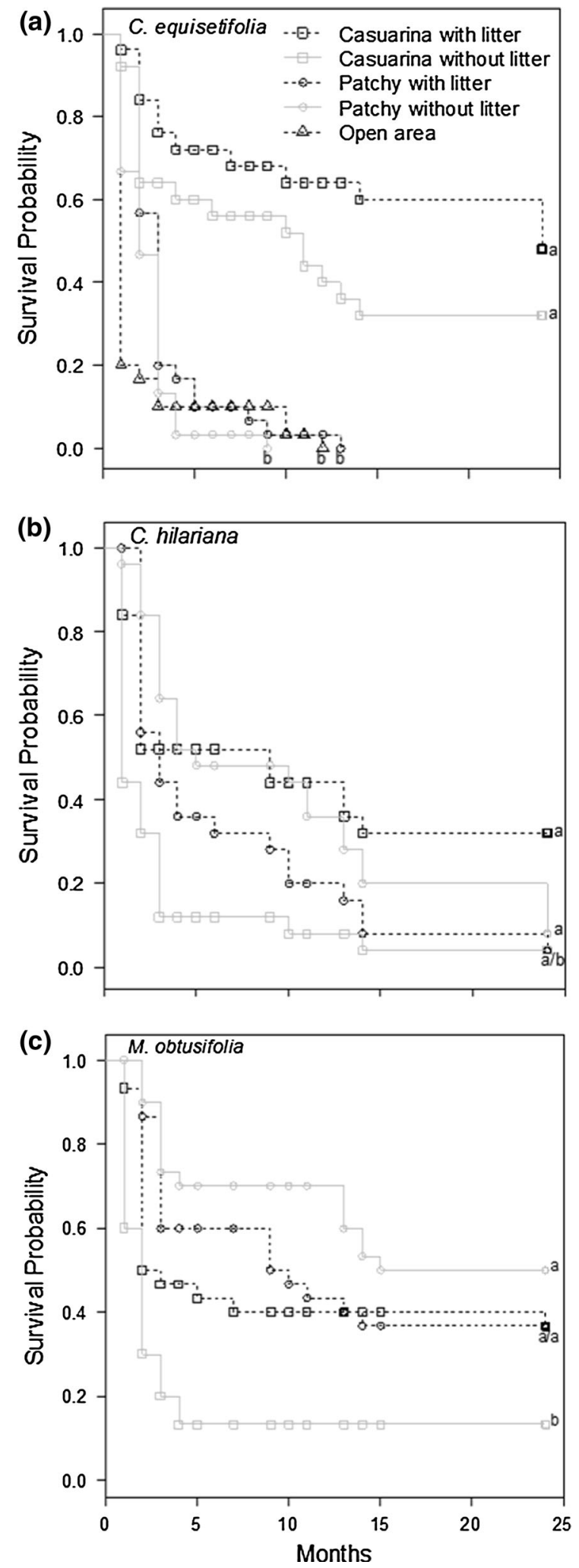
Fig. 4 Height increment for young plants of Casuarina equisetifolia transplanted to Casuarina stand (a), and Clusia hilariana (b) and Maytenus obtusifolia (c) transplanted to Casuarina stand and vegetation patches in the first (2014) and in the second (2015) year (except for $C$. hilariana) after planting in the restinga of the Costa do Sol State Park (Brazil). The letter codes indicate homogeneous groups (GLM, $p<0.05)$

As almost all young plants of $C$. equisetifolia died before 12 months inside vegetation patches, growth of this species was recorded only in the Casuarina stand, and there was no significant difference between height increment with and without a litter layer in both years (Fig. 4a; Table 5). Growth for C. hilariana was recorded only in the first year, because most labeled young plants died in the second year. There was no significant difference in height increment for both native species in the first year and for M. obtusifolia in the second year between the Casuarina stand and vegetation patches (Fig. 4b, c; Table 5). Litter layer also did not affect growth of native species (Table 5). The increase of the number of leaves was higher under Casuarina stand than inside vegetation patches for both native species in the first year, but in the second year there was no significant difference for $M$. obtusifolia (Fig. 5; Table 5).

Greenhouse experiments

There was no significant variation in percentage emergence for the three species in relation to soil type. However, emergence rate was significantly higher in soil from patches than in soil collected from the Casuarina stand (for both sterilized and nonsterilized treatments), except for $C$. hilariana. The highest moisture content was also in soil from patches (Table 6).

Seedling emergence of $C$. equisetifolia was influenced by the seed sowing position in the litter, with the highest emergence in the control. Emergence percentage and emergence rate was significantly lower below plastic fibers than below litter layer. For $C$. hilariana and M. obtusifolia the presence and type of litter layer had no significant effect on the emergence percentage. Litter significantly reduced emergence rate compared to the control treatment, and Casuarina litter and plastic fibers had similar effects for the two native species. No seedlings emerged from the seeds
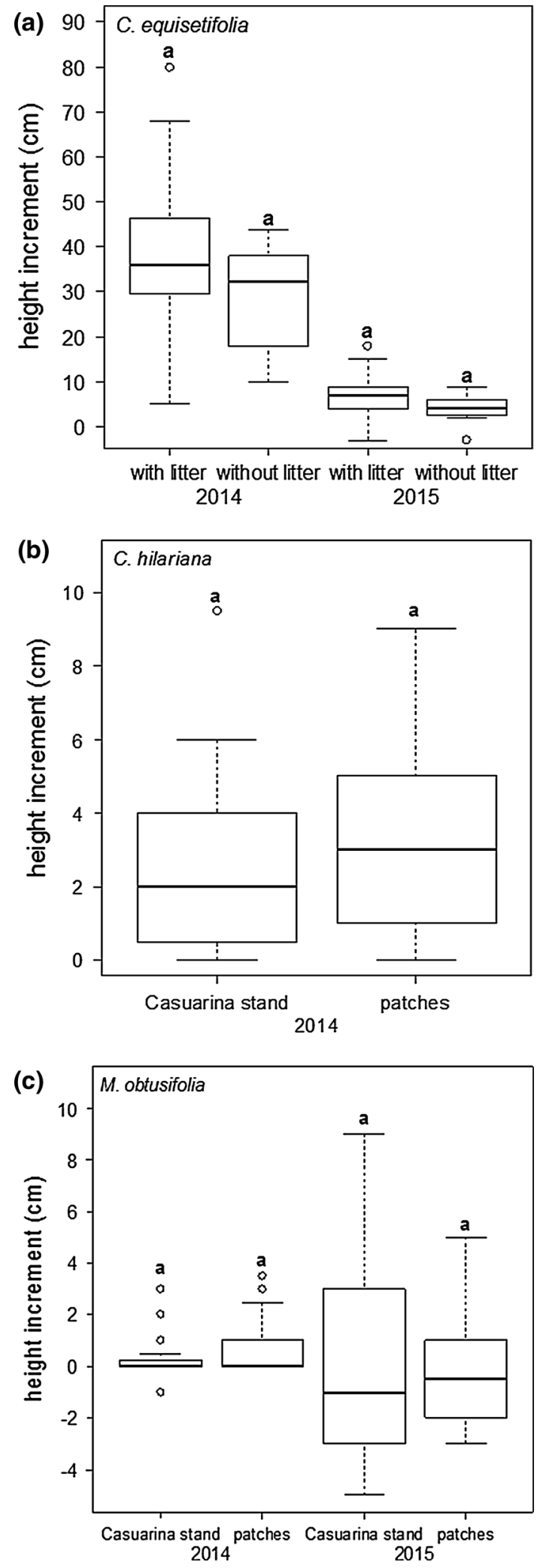
Table 5 Statistics for fixed effects of generalized linear model for young plants growth of Casuarina equisetifolia transplanted to Casuarina stand, and Clusia hilariana and Maytenus obtusifolia transplanted to Casuarina stand and vegetation patches in the first (2014) and in the second (2015) year (except C. hilariana) after planting in the restinga of the Costa do Sol State Park (Brazil)

\begin{tabular}{|c|c|c|c|c|}
\hline Variable & Estim. & SE & t value & $p$ \\
\hline \multicolumn{5}{|l|}{ Height increment } \\
\hline \multicolumn{5}{|c|}{ Casuarina equisetifolia (Casuarina stand) } \\
\hline \multicolumn{5}{|l|}{ Year 1 (2014) } \\
\hline Intercept & 3.67 & 0.10 & 36.18 & $<0.001$ \\
\hline Without-litter & -0.29 & 0.19 & -1.45 & 0.16 \\
\hline \multicolumn{5}{|l|}{ Year 2 (2015) } \\
\hline Intercept & 6.85 & 1.48 & 4.62 & $<0.001$ \\
\hline Without-litter & -2.99 & 2.51 & -1.19 & 0.25 \\
\hline \multicolumn{5}{|l|}{ Clusia hilariana } \\
\hline \multicolumn{5}{|l|}{ Year 1 (2014) } \\
\hline Intercept & 0.86 & 0.28 & 3.09 & 0.005 \\
\hline Patch & -0.24 & 1.31 & -0.18 & 0.85 \\
\hline Without-litter & 1.73 & 1.33 & 1.30 & 0.20 \\
\hline \multicolumn{5}{|c|}{ Maytenus obtusifolia } \\
\hline \multicolumn{5}{|l|}{ Year 1 (2014) } \\
\hline Intercept & 0.40 & 0.28 & 1.40 & 0.16 \\
\hline Patch & 0.54 & 0.35 & 1.55 & 0.13 \\
\hline Without-litter & -0.48 & 0.33 & -1.46 & 0.15 \\
\hline \multicolumn{5}{|l|}{ Year 2 (2015) } \\
\hline Intercept & -0.14 & 0.80 & -0.17 & 0.86 \\
\hline Patch & -0.49 & 0.97 & -0.51 & 0.61 \\
\hline Without-litter & 0.61 & 0.93 & 0.66 & 0.52 \\
\hline \multicolumn{5}{|c|}{ Increase of the number of leaves } \\
\hline \multicolumn{5}{|l|}{ Clusia hilariana } \\
\hline \multicolumn{5}{|l|}{ Year 1 (2014) } \\
\hline Intercept & -2.29 & 1.13 & -2.03 & 0.06 \\
\hline Patch & -6.69 & 1.84 & -2.55 & 0.02 \\
\hline Without-litter & 1.85 & 1.86 & 0.99 & 0.33 \\
\hline \multicolumn{5}{|c|}{ Maytenus obtusifolia } \\
\hline \multicolumn{5}{|l|}{ Year 1 (2014) } \\
\hline Intercept & 3.41 & 1.59 & 2.15 & $\mathbf{0 . 0 3}$ \\
\hline Patch & -6.75 & 1.94 & -3.48 & 0.001 \\
\hline Without-litter & 0.12 & 1.81 & 0.07 & 0.95 \\
\hline \multicolumn{5}{|l|}{ Year 2 (2015) } \\
\hline Intercept & 1.02 & 1.35 & 0.76 & 0.45 \\
\hline Patch & -2.04 & 1.62 & -1.26 & 0.22 \\
\hline Without-litter & 3.18 & 1.56 & 2.04 & 0.06 \\
\hline
\end{tabular}

In bold are significant values $(p<0.05)$ of the two native species sown above litter. The moisture content in the control treatment was lower than in the two types of litter. There was no significant difference in moisture content between $C$. equisetifolia litter and plastic fibers (Table 6).

\section{Discussion}

Although the restinga has been exposed to propagule pressure from $C$. equisetifolia, seed dispersal of this species into this ecosystem is rare, and there was hardly any seedling emergence and no survival of young plants. While the species is highly invasive in many coastal areas around the world (Rejmánek and Richardson 2013; Potgieter et al. 2014), results of this study suggest that preserved fragments of restinga can resist invasion of this alien tree. In ecosystems characterized by multiple stressful conditions, abiotic barriers are the main factors limiting invasion (Zefferman et al. 2015). In relation to the re-colonization of native species, light availability and soil type are not the main factors responsible for low regeneration in the Casuarina stand. Litter appears to be the major factor to prevents seedling emergence. Nevertheless, once plants are established, litter increases the survival of young plants and improves the recovery of native species in the invaded stand (Fig. 6).

Seed dispersal may limit invasion and increase native re-colonization

Restinga sites experience strong winds (Barbiére 1984) and throughout the study period wind speeds of $80.2 \mathrm{~km} \mathrm{hr}^{-1}$ were recorded (May/2013; INMET 2014) in the restinga of PECSol. Therefore, we expected more $C$. equisetifolia seeds to be dispersed over greater distances than were measured in this study. Many alien tree species with seeds adapted for dispersal by wind frequently spread over hundreds of meters or even kilometers (e.g. Pinus species; Richardson and Higgins 1998). Despite apparent adaptations for long-distance dispersal by wind (small seed size and membranous samaras), only $0.5 \%$ of the total C. equisetifolia seeds were dispersed between 50 and 100 meters from the edge of the Casuarina stand. A similar pattern was reported for dispersal of the 


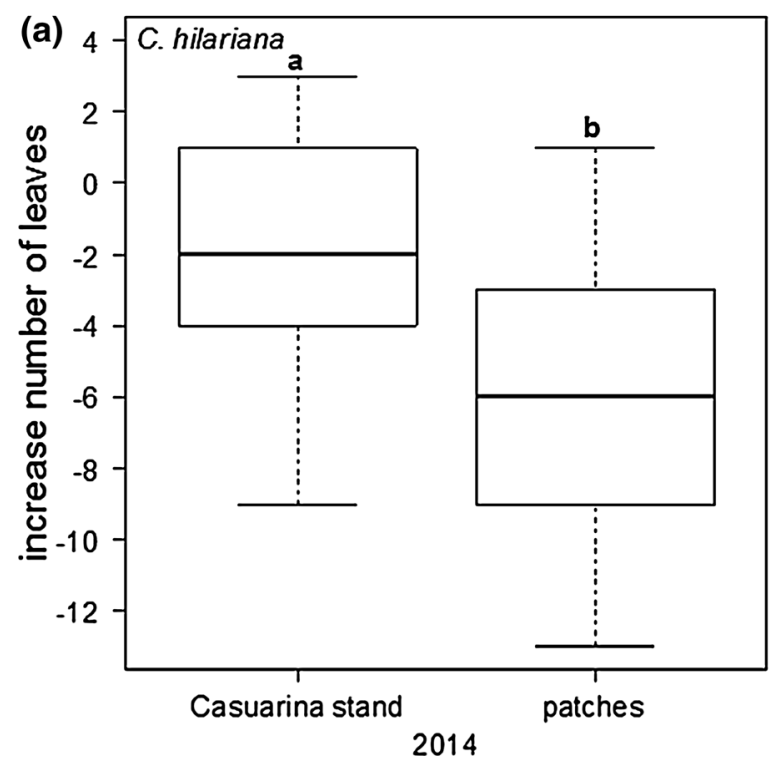

Fig. 5 Increase number of leaves for young plants of Clusia hilariana (a) and Maytenus obtusifolia (b) transplanted to Casuarina stand and vegetation patches in the first (2014) and in

wind-dispersed invasive tree Pinus elliottii in the restinga; $98 \%$ of the seeds of the pine were dispersed inside or at the edge of the pine stand, with only $2 \%$ moving $30 \mathrm{~m}$ beyond the pine stand (Bechara et al. 2013). Thus, although strong winds occur frequently in the restinga, long-distance seed dispersal of $C$. equisetifolia into this ecosystem does not appear to pose a major problem for conservation of this vegetation type (although further research on the dispersal dynamics of $C$. equisetifolia is justified). Seed dispersal by birds appears to be more effective in the restinga, in which seeds of zoochorous native species were dispersed to the Casuarina stand-for $M$. obtusifolia in the same quantity as in the restinga. Casuarina equisetifolia trees can act as perches, increasing the dispersal rate of native species dispersed by birds and potentially favoring colonization of native species in invaded areas.

Litter can limit or increase seedling emergence and establishment in invaded stands

Although for C. equisetifolia the number of emerged seedlings as a proportion of the number of dispersed seeds was similar in the Casuarina stand and in vegetation patches, the causes of the low emergence and null establishment in the two vegetation types

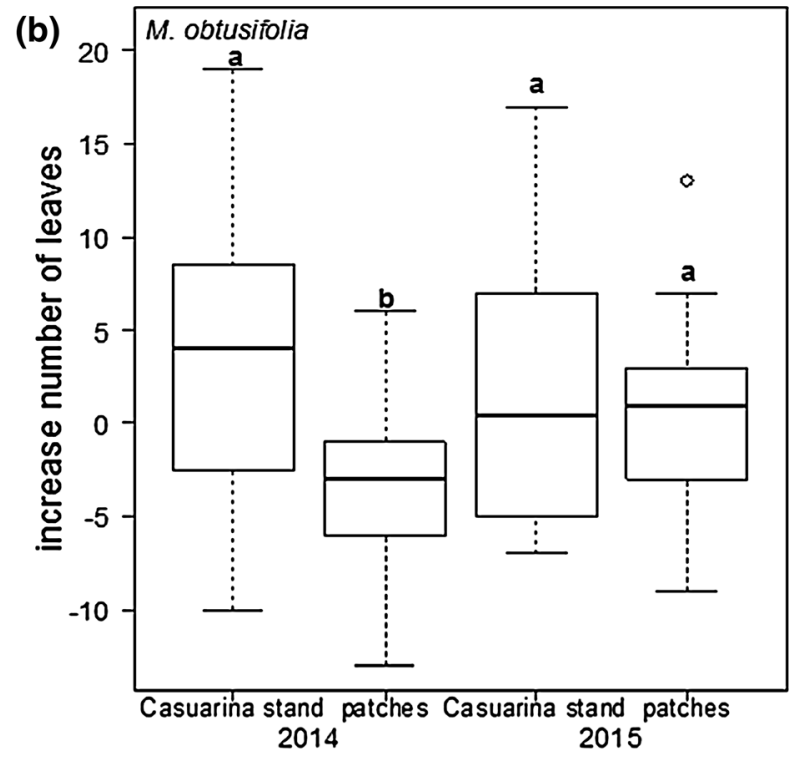

the second (2015) year (except for C. hilariana) after planting in the restinga of the Costa do Sol State Park (Brazil). The letter codes indicate homogeneous groups (GLM, $p<0.05$ )

should be different. The fact that emergence was almost nil under canopies of Casuarina trees in the field and in the greenhouse with the presence of litter (above or below) strongly suggests that Casuarina litter may be the main barrier limiting its own species recruitment in the Casuarina stand. In the restinga, the absence of seedlings in sown patches and in open areas could reflect the lack of suitable germination microsites. As C. equisetifolia is intolerant of shade, and since water stress limits germination of its seeds (Zimmermann et al. 2016), shade inside vegetation patches and dry conditions in open areas may be the main ecological mechanisms impeding its invasion in the restinga. Abiotic resistance is therefore the main factor thwarting invasion of $C$. equisetifolia in this ecosystem. Nonetheless, its seeds have the potential to remain viable for approximately 50 months in the soil (Zimmermann et al. 2016), and thus have the capacity to germinate whenever environmental conditions are favorable for germination (Baskin and Baskin 2014), allowing it to colonize new habitats.

Clusia hilariana is an important species contributing to seed dispersal of the restinga. However, like $C$. equisetifolia, it did not recruit in the two vegetation types. In the restinga, the infrequent establishment of C. hilariana (Dias et al. 2005) occurs mainly inside the tank of soil bromeliads in vegetation patches (Zaluar 


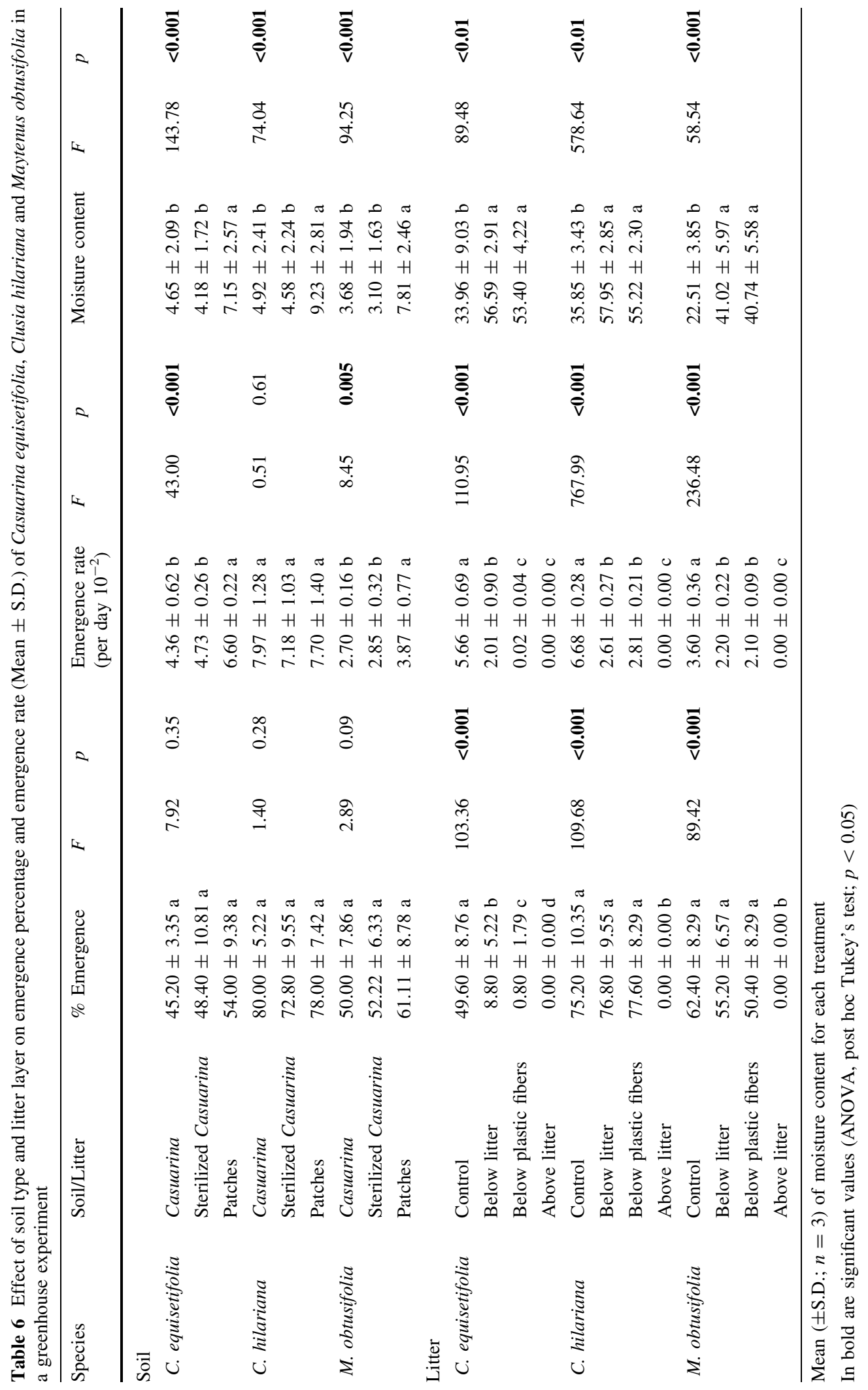


Fig. 6 Interaction model among Casuarina equisetifolia, Clusia hilariana and Maytenus obtusifolia in the Casuarina stand and restinga (inside vegetation patches). Positive or negative signs $(+,-)$ indicate possible outcomes for seed dispersal, seedling emergence and young plants survival of the species in each vegetation

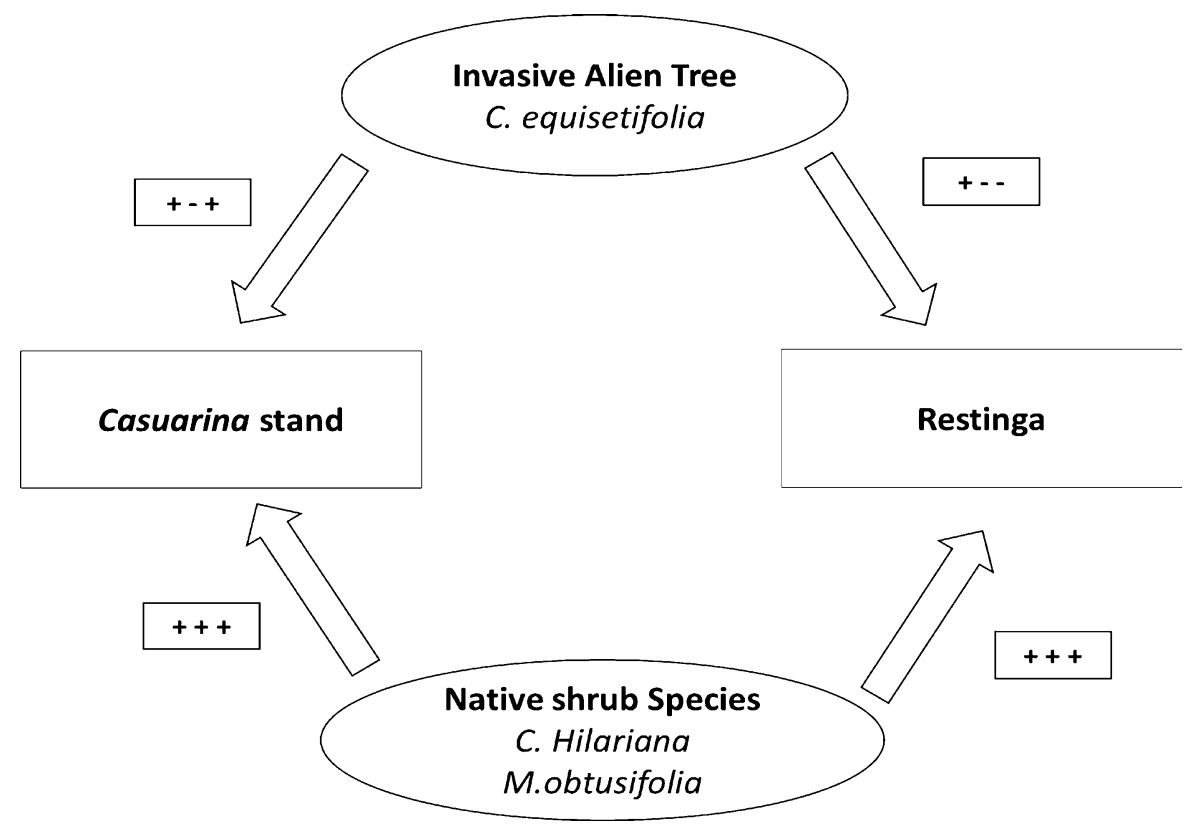

and Scarano 2000). The likelihood of a dispersed $M$. obtusifolia seed becoming an established seedling was almost five times higher in the Casuarina stand below litter than inside vegetation patches. This helps to drive recolonization of native shrubs in areas invaded by this alien species (Hata et al. 2012). In addition, seedlings of $M$. obtusifolia survived longer than 24 months in both vegetation types, probably due to seedling morphology. Seeds of this species have cotyledon reserves that provide a nutritional supplement to boost embryo growth and seedling survival (Garwwod 1996), thus increasing the likelihood for successful plant establishment in ecosystems with multiple stressful conditions.

Unlike seeds sown below litter, seedling emergence of native species rarely occurred for those sown on top of the litter in the field and in the greenhouse. Litter prevents seed from reaching the soil surface, acting as a physical barrier to dispersing seeds and limiting seedling establishment (West et al. 2014). However, if seeds can penetrate the litter layer they can germinate and seedlings may establish. As there was no differences between levels of seedling emergence below plastic fibers and plant litter in the greenhouse, the negative effect of $C$. equisetifolia litter on seedling emergence must be physical rather than chemical; this agrees with results from other studies (Rotundo and Aguiar 2005; Hovstad and Ohlson 2008).
Nevertheless, Nakahira and Ohira (2005) detected allelochemicals in leachates of C. equisetifolia litter in bioassay experiments. Further studies are therefore needed to evaluate the response of native species to the allelopathic potential of this alien species.

Differences in light availability between the invaded and preserved restinga had less effect than the presence of litter layer on seedling emergence of native species. This is in contrast to results from a subtropical island, where the difference in the seedling establishment of a native shrub between a $C$. equisetifolia stand and a native forest was explained by the forest type rather than the presence of litter (Hata et al. 2010a). In ecosystems with dry conditions, like the restinga, the litter layer can improve soil moisture, which may increase seedling establishment (Xiong and Nilsson 1999; Warren et al. 2012). This is the main reason why the absence of litter also reduced seedling emergence of native species in the field. Similarly, Hata et al. (2012) observed that removal of litter reduced seedling establishment of a native shrub in an area invaded by $C$. equisetifolia.

As $C$. equisetifolia produces abundant litter with a low decomposition rate and high toxic concentrations of selenium and salts (Parrotta 1993), the release of allelochemicals in the soil of the invaded area as litter decomposed was expected (Wardle et al. 1996). Nevertheless, soil type did not affect the percentage 
of seedling emergence; this finding is in line with the results of Hata et al. (2010a) who observed no differences in seedling emergence of a native shrub between soil from a C. equisetifolia forest and from a native forest. These results thus strongly suggest that soil in the Casuarina stand did not present biochemical compounds that limit plant recruitment. However, soil in the Casuarina stand decreased emergence rate in the greenhouse. The highest emergence in soil from patches may be due the high level of soil moisture, which may have accelerated the germination process (Baskin and Baskin 2014).

Litter can improve native plant survival in invaded stands

As for seedlings, no incidence of herbivory was observed and abiotic filters were the main cause of mortality of young plants. Unlike for seedling emergence and establishment, light availability is an important mediator for young plants survival, especially for shade-intolerant species like $C$. equisetifolia (Zimmermann et al. 2016). Although all plants of $C$. equisetifolia died in the restinga, disturbance that increases light availability (i.e. canopy disturbance) mainly near water bodies could improve its survival in this ecosystem and enhance its spread to adjacent vegetation. In the Casuarina stand the probability of its survival is high if the species overcome the seedling phase, increasing its population density.

The high canopy cover (1.7\% of light; Matos 2014) should reduce water evaporation inside patches, thus differences in soil water content with presence or absence of litter did not influence survival of young plants in this microsite. Unlike in the Casuarina stand, litter improved native plants survival, mainly due the high light conditions in this vegetation (68.5\% light; Zimmermann et al. 2016). Although the CAM photosynthesis (Franco et al. 1996) maximizes water use efficiency, mortality of young plants of $C$. hilariana due to summer drought stress was an important filter for this species. January and February 2015 were very dry months (0.2 and $19 \mathrm{~mm}$, respectively, Figure S1), and may have contributed to the high mortality rate of this native shrub after one year of planting in both vegetation types. Maytenus obtusifolia had the highest seedling emergence in the invaded area, however, vegetation patches provide the best conditions for its survival. As C. hilariana and M. obtusifolia cannot tolerate high light conditions (Matos 2014) and the area invaded by $C$. equisetifolia did not form a closed stand, with some regions under full sunlight conditions, photodestruction may be the main cause of death for both native species.

Litter can be important for survival in the Casuarina sand, but did not increase growth of young plants. Although survival of both native plants was low in the invaded area, they grew during the two years, mainly the number of leaves in the first year, which suggests that they may persist and aid in the colonization of the Casuarina stand. On the other hand, high survival and relative growth rates of $C$. equisetifolia in the Casuarina stand could indicate that the species is competitively superior to native plants, which would allow it to obtain resources more effectively than the slower growing native species (Grotkopp and Rejmánek 2007; Stricker and Stiling 2013). Thus, although native species can colonize the invaded area, the capacity of $C$. equisetifolia to develop monospecific stands could suppress potential re-colonization of the native plants.

Implications for conservation of sandy coastal plains

Although $C$. equisetifolia is an early successional species, with many traits of successful invasive trees, such as rapid-growth, short juvenile period, small seeds and high seed production (Rejmánek and Richardson 1996; Richardson 2006), our study suggests that the spread of this alien species into the preserved restinga is strongly limited by abiotic barriers. As the tree is sensitive to both drought and shade, this resistance is mainly attributable to the scarcity of key resources in this ecosystem, especially low light inside vegetation patches and water stress in open areas. Nevertheless, anthropogenic disturbances are increasing opportunities for invasion by altering the key processes that naturally make the restinga resistant to invasion. Canopy disturbance in areas close to water bodies would therefore decrease resistance to tree invasion at sites where seed dispersal is not limiting, opening the door to negative impacts on the regional biodiversity. Thus, one of the best ways of hampering invasion of $C$. equisetifolia in the restinga is to conserve the remaining fragments.

Light conditions and soil type do not appear to create major barriers to the recruitment of native plant 
in the Casuarina stand. Accumulation of large amounts of litter is one of the main causes of low establishment in the invaded area; this affects successional pathways on sandy coastal plains. As removal of C. equisetifolia is difficult because it has capacity for vegetative regrowth (Morton 1980) and long-term seed persistence in the soil (Zimmermann et al. 2016), other options need to be explored to aid native species recovery in invaded areas. One option is to manage these "novel ecosystems" to enhance the persistence and regeneration of native plant species. A key intervention towards achieving such an aim should involve sowing seeds below litter and planting young plants of native shrubs with litter. Knowledge of the mechanisms that mediate persistence and re-colonization of native species, as detailed in this study, is crucial elements for effective management of the invaded stands.

Acknowledgments Funding for this project was provided by the Instituto de Pesquisas Jardim Botânico do Rio de Janeiro (JBRJ), Coordenação de Aperfeiçoamento de Pessoal de Nível Superior (CAPES) and Fundação de Amparo à Pesquisa do Estado do Rio de Janeiro (FAPERJ). We thank, F. Silva and I.S. Matos for their field assistance and L.L. Leal for her assistance in the greenhouse. DMR acknowledges funding from the DSTNRF Centre of Excellence for Invasion Biology and the National Research Foundation of South Africa (grant 85417).

\section{Compliance with ethical standards}

Conflict of interest The authors declare that they have no conflict of interest.

\section{References}

Apfelbaum SI, Ludwig JP, Ludwig C (1983) Ecological problems associated with disruption of dune vegetation dynamics by Casuarina equisetifolia L. at Sand Island, Midway Atoll. Atoll Res Bull 261:1-19

Araújo DSD (1992) Vegetation types of sandy coastal plains of tropical Brazil: a first approximation. In: Seeliger U (ed) Coastal plant communities of Latin America. Academic Press, San Diego, pp 337-347

Araújo DSD, Pereira MCA (2002) Sandy coastal vegetation. Eolss Publishers, International Commission on Tropical Biology and Natural Resources, Oxford

Araújo DSD, Sá CFC, Fontella-Pereira J, Garcia DS, Ferreira MV, Paixão RJ, Schneider SM, Fonseca-Kruel VS (2009) Área de proteção ambiental de Massambaba, Rio de Janeiro: caracterização fitofisionômica e florística. Rodriguésia 60:67-96

Bais HP, Vepachedu R, Gilroy S, Callaway RM, Vivanco JM (2003) Allelopathy and exotic plant invasion: from molecules and genes to species interactions. Science 301:1377-1380

Barbiére EB (1984) Cabo Frio e Iguaba Grande, dois microclimas distintos a um curto intervalo espacial. In: Lacerda LD, Araújo DDD, Cerqueira R, Turcq B (eds) Restingas: origem, estrutura, processos. CEUFF, Niterói, pp 3-13

Barroso GM, Morim MP, Peixoto AL, Ichaso CLF (1999) Frutos e sementes: morfologia aplicada à sistemática de dicotiledôneas. Universidade Federal de Viçosa, Viçosa

Baskin CC, Baskin JM (2014) Seeds: Ecology, biogeography, and evolution of dormancy and germination 2nd. Elsevier, San Diego

Bechara FC, Reis A, Bourscheid K, Vieira NK, Trentin BE (2013) Reproductive biology and early establishment of Pinus elliottii var. elliottii in Brazilian sandy coastal plain vegetation: implications for biological invasion. Sci Agric 702:88-92

Benevides CR, Haddad IVN, Barreira NP, Rodarte ATA, Galetto L, Santiago-Fernandes LDR, Lima HA (2013) Maytenus obtusifolia Mart. (Celastraceae): a tropical woody species in a transitional evolutionary stage of the gynodioecy-dioecy pathway. Plant Syst Evol 299:1693-1707

Bittrich V, Trad RJ, Cabral FN, Nascimento-Jr JE, Souza VC (2015) Clusiaceae in Lista de Espécies da Flora do Brasil. Jardim Botânico do Rio de Janeiro. http://floradobrasil.jbrj. gov.br/jabot/floradobrasil/FB6836. Accessed 28 Aug 2015

Blackburn TM, Pyšek P, Bacher S, Carlton JT, Duncan RP, Jarošík V, Wilson JRU, Richardson DM (2011) A proposed unified framework for biological invasions. Trends Ecol Evol 26:333-339

Braz MIG, de Mattos EA (2010) Seed dispersal phenology and germination characteristics of a drought-prone vegetation in southeastern Brazil. Biotropica 42:327-335

Callaway RM, Walker LR (1997) Competition and facilitation: a synthetic approach to interactions in plant communities. Ecology 78:1958-1965

Cavalcante A, Braz MIG, de Mattos EA (2010) Germination biology and seedling growth of Clusia hilariana Schltdl., a dominant CAM-tree of drought-prone sandy coastal plains. Ecol Res 25:781-787

Cavalin PO, de Mattos EA (2007) Spatio-temporal variation of photosynthetic pigments in CAM tree Clusia hilariana Schlechtendal associated with dry spells during rainy season in south-eastern Brazil. Trees 21:671-675

Correia CMB, Dias ATC, Scarano FR (2010) Plant-plant associations and population structure of four woody plant species in a patchy coastal vegetation of Southeastern Brazil. Rev Bras Biol 33:607-613

Coutts SR, van Klinken RD, Yokomizo H, Buckley YM (2011) What are the key drives of spread in invasive plants: dispersal, demography or landscape: and can we use this knowledge to aid management? Biol Invasions 13:1649-1661

de la Penã E, Bonte D, Roiloa S, Rodíguez-Echeverría S, Freitas H (2010) Plant-soil feedback as mechanism of invasion by Carpobrotus edulis. Biol Invasions 12:3637-3648

Dechoum MS, Zenni RD, Castellani TT, Zalba SM, Rejmánek M (2015) Invasions across secondary forest successional stages: effects of local plant community, soil, litter, and herbivory on Hovenia dulcis seed germination and seedling establishment. Plant Ecol 216:823-833 
Dias ATC, Zaluar HLT, Ganade G, Scarano FR (2005) Canopy composition influencing plant patch dynamics in a Brazilian sandy coastal plain. J Trop Ecol 21:343-347

Dias ATC, de Mattos EA, Vieira SA, Azeredo JV, Scarano FR (2006) Aboveground biomass stock of native woodland on a Brazilian sandy coastal plains: estimates based on the dominant tree species. For Ecol Manag 226:364-367

Eckstein RL, Donath TW (2005) Interactions between litter and water availability affect seedling emergence in four familial pairs of floodplain species. J Ecol 93:807-816

Emer C, Fonseca CR (2011) Araucaria Forest conservation: mechanisms providing resistance to invasion by exotic timber tress. Biol Invasions 13:189-202. doi:10.1007/ s10530-010-9801-0

Ens E, French K (2008) Exotic woody invader limits the recruitment of three indigenous plant species. Biol Conserv 141:590-595

Facelli JM, Pickett STA (1991) Plant litter: its dynamics and effects on plant community structure. Bot Rev 57:1-32

Faria APG, Matallana G, Wendt T, Scarano FR (2006) Low fruit set in the abundant dioecious tree Clusia hilariana (Clusiaceae) in a Brazilian restinga. Flora 201:606-611

Franco AC, Haag-Kerwer A, Herzog B, Grams T, Ball E, de Mattos EA, Scarano FR, Barreto SMB, Garcia MA, Mantovani A, Lutge U (1996) The effect of light levels on daily patterns of chlorophyll fluorescence and organic acid accumulation in the tropical CAM tree Clusia hilariana. Trees 10:359-365

Fuentes-Ramírez A, Pauchard A, Cavieres LA, García RA (2011) Survival and growth of Acacia dealbata vs. native trees across an invasion front in south-central Chile. Forest Ecol Manag 261:1003-1009

Garwwod NC (1996) Functional morphology of tropical tree seedlings. In: Swaine MD (ed) The ecology of tropical forest tree seedlings man and the biosphere. Parthenon Publishing Group, New York, pp 59-129

Gomes VSM (2006) Variação espacial e dieta de aves terrestres na Restinga de Jurubatiba, RJ. PhD Thesis, Universidade Federal do Rio de Janeiro

Gómez-Aparicio L, Valladares F, Zamora R, Quero JL (2005) Response of tree seedlings to the abiotic heterogeneity generated by nurse shrubs: an experimental approach at different scales. Ecography 28:757-768

Grotkopp E, Rejmánek M (2007) High seedling relative growth rate and specific leaf area are traits of invasive species: phylogenetically independent contrasts of woody angiosperms. Am J Bot 94:526-532

Guerrero PC, Bustamante RO (2007) Can Native Tree Species Regenerate in Pinus radiata Plantations in Chile? evidence from field and laboratory experiments. Forest Ecol Manag 253:97-102

Hastwell GT, Facelli JM (2003) Differing effects of shade-induced facilitation on growth and survival during the establishment of a chenopod shrub. J Ecol 91:941-950

Hata K, Kato H, Kachi N (2009) Community structure of saplings of native woody species under forests dominated by alien woody species, Casuarina equisetifolia, in Chichijima Island. Ogasawara Res 34:33-50

Hata K, Kato H, Kachi N (2010a) Litter of an alien tree, Casuarina equisetifolia, inhibits seed germination and initial growth of a native tree on the Ogasawara Islands (subtropical oceanic islands). J For Res 15:384-390

Hata K, Kato H, Kachi N (2010b) Litterfall in forests dominated by an alien woody species, Casuarina equisetifolia, on Chichijima Island. Ogasawara Res 35:1-14

Hata K, Kato H, Kachi N (2012) Seedlings of a native shrub can establish under forests dominated by an alien tree, $\mathrm{Ca}$ suarina equisetifolia, on subtropical oceanic islands. J For Res 17:208-212

Hesp PA, Martínez ML (2007) Disturbance processes and dynamics in coastal dunes. In: Johnson EA, Miyanishi K (eds) Plant disturbance ecology. The process and the response. Academic Press, San Diego, pp 215-247

Hobbs RJ, Higgs ES, Hall CM et al (2014) Managing the whole landscape: historical, hybrid and novel ecosystems. Front Ecol Environ 12:557-564

Holmes PM, Richardson DM (1999) Protocols for restoration based on recruitment dynamics, community structure and ecosystem function: perspectives from South African fynbos. Restor Ecol 7:215-230

Hovstad KA, Ohlson M (2008) Physical and chemical effects of litter on plant establishment in semi-natural grasslands. Plant Ecol 196:251-260

Hulme PE (2007) Biological invasions in Europe: drivers, pressures, states, impacts and responses. In: Hester R, Harrison RM (eds) Biodiversity under Threat. Cambridge University Press, Cambridge, pp 56-80

Inderjit Seastedt TR, Callaway RM, Pollock JL, Kaur J (2008) Allelopathy and plant invasions: traditional, congeneric, and bio-geographical approaches. Biol Invasions 10:875-890

INMET (2014) Instituto Nacional de Meteorologia. http://inmet. gov.br. Acessed 15 Jul 2014

I3N Brazil. 2016. Base de dados nacional de espécies exóticas invasoras, I3N Brasil, Instituto Hórus de desenvolvimento e Conservação Ambiental. http://i3n.institutohorus.org.br. Accessed 12 Jan 2016

Lacerda LD, Araújo DSD, Maciel NC (1993) Dry coastal ecosystems of the tropical Brazilian coast. In: Van der Maarel E (ed) Dry coastal ecosystems: Africa, America, Asia, Oceania. Elsevier, Amsterdam, pp 477-493

Levine JM, Adler PB, Yelenik SG (2004) A meta-analysis of biotic resistance to exotic plant invasions. Ecol Lett 10:975-989

Lombardi J, Groppo M, Biral L (2015) Celastraceae in Lista de Espécies da Flora do Brasil. Jardim Botânico do Rio de Janeiro. http://floradobrasil.jbrj.gov.br/jabot/floradobrasil/ FB6766. Accessed 28 Aug 2015

Lonsdale WM (1999) Global patterns of plant invasions and the concept of invasibility. Ecology 80:1522-1536

Loydi A, Donath TW, Eckstein RL, Otte A (2015) Non-native species litter reduces germination and growth of resident forbs and grasses: allelopathic, osmotic or mechanical effects? Biol Invasions 17:581-595

Matos IS (2014) Crescimento, Sobrevivência e Plasticidade Fenotípica de Plântulas de Espécies de Restinga sob Gradientes Experimentais de Intensidade de Luz e de Disponibilidade Hídrica. Dissertation, Instituto de Pesquisas Jardim Botânico do Rio de Janeiro

McAlpine KG, Jesson LK (2008) Linking seed dispersal, germination and seedling recruitment in the invasive species 
Berberis darwinii (Darwin's barberry). Plant Ecol 197:119-129

Morton JF (1980) The Australian pine or beefwood (Casuarina equisetifolia L.) an invasive "weed" tree in Florida. Proc Fl State Horticult Soc 93:87-95

Nakahira Y, Ohira T (2005) Study on the allelopathy of $\mathrm{Ca}$ suarina glauca and $C$. equisetifolia. Kyushu J For Res 58:159-161

Novoa A, González L, Moravcová L, Pyšek P (2012) Effects of soil characteristics, allelopathy and frugivory on establishment of the invasive plant Carpobrotus edulis and a cooccuring native Malcolmia littorea. PLoS One 7(12):e53166

Novoa A, Rodríguez R, Richardson D, González L (2014) Soil quality: a key factor in understanding plant invasion? the case of Carpobrotus edulis (L.) N.E.Br. Biol Invasions 16:429-443

Parrotta JA (1993) Casuarina equisetifolia L. ex J.R. and G. Forst. SO-ITF-SM-46. International Institute of Tropical Forestry, U.S. Department of Agriculture, Forest Service, Puerto Rico

Parrotta JA (1995) Influence of overstory composition on understory colonization by native species in plantations on a degraded tropical site. J Veg Sci 6:627-636

Parrotta JA (1999) Productivity, nutrient cycling and succession in single- and mixed-species plantations of Casuarina equisetifolia, Eucalyptus robusta and Leucaena leucocephala in Puerto Rico. For Ecol Manag 90:45-77

Pimentel D, Lach L, Zuniga R, Morrison D (2000) Environmental and economic costs of non-indigenous species in the United States. Bioscience 50:53-65

Potgieter LJ, Richardson DM, Wilson JRU (2014) Casuarina: biogeography and ecology of an important tree genus in a changing world. Biol Invasions 16:609-633

Pugnaire FI, Armas C, Valladares F (2004) Soil as a mediator in plant-plant interactions in a semi-arid community. J Veg Sci 15:85-92

R Core Team (2014) R: a language and environment for statistical computing. R Foundation for Statistical Computing, Vienna. Available via http://www.R-project.org/

Reinert F, Roberts A, Wilson JM, de Ribas L, Cardinot G, Griffiths H (1997) Gradation in nutrient composition and photosynthetic pathways across the restinga vegetation of Brazil. Bot Acta 110:135-142

Rejmánek M, Richardson D (1996) What attributes make some plant species more invasive? Ecology 77:1655-1661

Rejmánek M, Richardson DM (2013) Trees and shrubs as invasive alien species - 2013 update of the global database. Divers Distrib 19:1093-1094

Rentería JL (2007) Plan de manejo para la erradicación de Casuarina equisetifolia L. (Casuarinaceae), especie invasora de limitada distribución en la isla Santa Cruz, Galápagos. Estación Científica Charles Darwin, Galápagos, Ecuador

Richardson DM (2006) Pinus: a model group for unlocking the secrets of alien plant invasions? Preslia 78:375-388

Richardson DM, Higgins SI (1998) Pines as invaders in the southern hemisphere. In: Richardson DM (ed) Ecology and biogeography of Pinus. Cambridge University Press, Cambridge, pp 450-473
Richardson DM, Pyšek P (2012) Naturalization of introduced plants: ecological drivers of biogeographic patterns. New Phytol 196:383-396

Rocha CFD, Van Sluys M, Alves MS, Jamel CE (2007) The remnants of restinga habitats in the Brazilian Atlantic Forest of Rio de Janeiro state, Brazil: habitat loss and risk of disappearance. Braz J Biol 67:263-273

Rotundo JL, Aguiar MR (2005) Litter effects on plant regeneration in arid lands: a complex balance between seed retention, longevity and soil-seed-contact. $\mathrm{J}$ Ecol 93:829-838

Rouget M, Robertson MP, Wilson JRU, Hui C, Essl F, Renteria JL, Richardson DM (2016) Invasion debt-quantifying future biological invasions. Divers Distrib 22:445-456

Scarano FR (2002) Structure, function and floristic relationships of plant communities in stressful habitats marginal to the Brazilian Atlantic Rainforest. Ann Bot 90:517-524

Scarano FR (2009) Plant communities at the periphery of the Atlantic rain forest: rare-species bias and its risks for conservation. Biol Conserv 142:1201-1208

Stricker KB, Stiling P (2013) Seedlings of the introduced invasive shrub Eugenia uniflora (Myrtaceae) outperform those of its native and introduced non-invasive congeners in Florida. Biol Invasions 15:1973-1987. doi:10.1007/ s10530-013-0425-Z

van Wilgen BW, Fill JM, Baard J, Cheney C, Forsyth AT, Kraaij $\mathrm{T}$ (2016) Historical costs and projected future scenarios for the management of invasive alien plants in protected areas in the Cape Floristic Region. Biol Conserv 200:168-177

Vilà M, Lloret F (2000) Seed dynamics of the mast seeding tussock grass Ampelodesmos mauritanica in Mediterranean shrublands. J Ecol 88:479-491

Vilà M, Espinar JL, Hejda M et al (2011) Ecological impacts of invasive alien plants: a meta-analysis of their effects on species, communities and ecosystems. Ecol Lett 14:702-708

Wardle DA, Nicholson KS, Rahman A (1996) Use of a comparative approach to identify allelopathic potential and relationship between allelopathy bioassays and "competition" experiments for ten grassland and plant species. J Chem Ecol 22:933-994

Warren RJ, Bahn V, Bradford MA (2012) The interaction between propagule pressure, habitat suitability and density-dependent reproduction in species invasion. Oikos 121:874-881

West NM, Matlaga DP, Davis AS (2014) Quantifying targets to manage invasion risk: light gradients dominate the early regeneration niche of naturalized and pre-commercial Miscanthus populations. Biol Invasions 16:1991-2001

Whistler WA, Elevitch CR (2006) Casuarina equisetifolia (reach she-oak) and C. cunninghamiana (river she-oak). In: Elevitch CR (ed) Species profiles for Pacific Island agroforestry. Permanent Agriculture Resources (PAR), Holualoa, Hawaii, p 16p

Xiong SJ, Nilsson C (1999) The effects of plant litter on vegetation: a meta-analysis. J Ecol 87:984-994

Zaluar HLT, Scarano FR (2000) Facilitação em restingas de moitas: um século de buscas por espécies focais. In: Esteves FA, Lacerda LD (eds) Ecologia de Restingas e Lagoas Costeiras. NUPEM-UFRJ, Rio de Janeiro, pp 3-23 
Zar JH (1999) Biostatistical Analysis, 4th edn. Prentice Hall, New Jersey

Zefferman E, Stevens JT, Charles GK, Dunbar-Irwin M, Emam T, Fick S, Morales SV, Wolf KM, Young DJN, Young TP (2015) Plant communities in harsh sites are less invaded: a summary of observations and proposed explanations. AoB PLANTS 7:plv056
Zenni RD, Ziller SR (2011) An overview of invasive plants in Brazil. Revista Brasil Bot 34:431-446

Zimmermann TG, Andrade ACS, Richardson DM (2016) Experimental assessment of factors mediating the naturalisation of a globally invasive tree on sandy coastal plains: a case study from Brazil. AoB PLANTS 8: plw042; doi: 10.1093/aobpla/plw042 